\title{
O PODER CONSTITUINTE ORIGINÁRIO E SUA LIMITAÇÃO MATERIAL PELOS TRATADOS INTERNACIONAIS DE DIREITOS HUMANOS
}

\author{
Ana Paula Barbosa de Sá*
}

\begin{abstract}
RESUMO
O presente trabalho tem por objetivo a análise da possível limitação material do poder constituinte originário nos dias atuais, em especial pelos tratados internacionais que versem sobre direitos humanos. Considerando que a teoria constitucional contemporânea está marcada, primordialmente, pela busca da democracia e que esta, por princípio, mantém uma relação de dependência com os direitos fundamentais dos indivíduos, a observância do teor dos tratados de direitos humanos pelo poder constituinte originário, tradicionalmente definido como absolutamente ilimitado, teria como objetivo único fortalecer os ideais democráticos, alcançando-se, por conseqüência, a crescente valorização da pessoa humana, na desejável consagração dos ditames da justiça social em escala mundial.
\end{abstract}

PALAVRAS-CHAVE: Poder Constituinte Originário. Tratados Internacionais de Direitos Humanos.

\begin{abstract}
The present essay aims at analyzing today's possible limitation of constituent power by international treaties on human rights. Whereas contemporary constitutional theory is marked primarily by the pursuit of democracy, that, in principle, maintain a dependent relationship with the fundamental rights of individuals, the compliance with human rights treaties by the constituent power, traditionally defined as absolutely unlimited, would aim only to strengthen democratic ideals, reaching up, as a consequence, the growing appreciation of the human person, in the consecration of social justice worldwide.
\end{abstract}

KEYWORDS: Constituent Power. International Treaties on Human Rights.

\section{CONSIDERAÇÕES INICIAIS}

O mundo contemporâneo tem assistido a um processo de mudanças profundas e bastante rápidas, originadas por acontecimentos históricos surgidos nas mais diversas partes do globo e que se perpetuam até os dias de hoje. O início do novo milênio sugere a manutenção deste panorama, dando continuidade a este ritmo de intensas transformações que

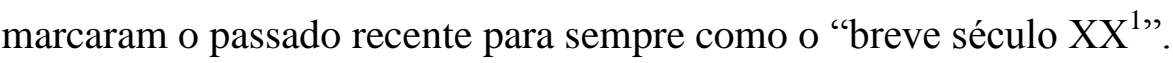

No âmbito dos Estados, tal situação teve uma inegável influência na organização das estruturas política, econômica e social, no que se inclui o Direito e, em especial, o Direito Constitucional. Várias foram as pressões sofridas pelos legisladores no sentido de adaptarem

\footnotetext{
${ }^{*}$ Mestre em Direito Público pela Universidade do Estado do Rio de Janeiro (UERJ). Advogada.

${ }^{1}$ A expressão é do historiador Eric Hobsbawm, 1995.
} 
os regramentos aos novos tempos e às novas exigências que daí decorreram, o que muitas vezes, paradoxalmente, resultou em severas críticas e grandes polêmicas.

De modo surpreendente, por outro lado, o tema relativo à doutrina do Poder Constituinte atravessou todo este período de forma praticamente incólume na concepção da maioria dos doutrinadores, como se o cenário de ativas transformações advindas das mais diferentes esferas, tanto no plano interno dos Estados como no internacional, em nada houvesse afetado o seu desenvolvimento e caracterização.

É impossível, entretanto, ignorar o fato de que, hoje, não se admite mais aceitar passivamente todos os pressupostos construídos no nascedouro da teoria do poder constituinte, tal como então idealizado pelo abade Sieyès, na França do século XVIII, sem questionar os seus fundamentos e o real posicionamento nos dias atuais.

Assim, se há relativo consenso em que, partindo-se da tradicional distinção entre poder constituinte originário e derivado (também denominado "constituído" ou "de reforma", entre outros), a definição clássica do primeiro "corresponde à possibilidade (poder) de elaborar e colocar em vigência uma Constituição em sua globalidade ${ }^{2 \%, ~ n a ̃ o ~ h a ́ ~ c o m o ~ n e g a r ~ a ~ e x i s t e ̂ n c i a ~}$ de controvérsias em torno, por exemplo, da legitimidade daqueles a quem foi conferido o seu exercício.

Indagações similares e, de certa maneira, estreitamente relacionadas ao tema da legitimidade, relacionam-se com a questão das eventuais limitações materiais ao exercício do poder constituinte originário, matéria bastante polêmica, por contrariar entendimentos em sentido oposto fortemente arraigados entre a maior parte da doutrina.

Por outro lado, ainda que, em um primeiro momento, não se possa vislumbrar uma relação direta entre os assuntos, ao se discutir a elaboração de um novo documento constitucional para o Estado, forçoso admitir que o fim último deste processo reside, sempre, na necessidade de garantir o bem-estar dos indivíduos que ali habitam. Por esta razão, o tema dos direitos humanos, objeto de intensos debates e acordos no plano mundial, adquire um papel de destaque e traz à luz uma nova perspectiva a ser considerada nesta situação.

Nesta ordem de idéias, o presente trabalho tem por objetivo a análise da possível limitação material do poder constituinte originário nos dias atuais, em especial pelos valores relacionados aos direitos humanos e os tratados que versem sobre a matéria. Para tanto, perscrutar-se-ão suas origens políticas e a posterior elaboração de sua teoria, sendo suscitadas

\footnotetext{
${ }^{2}$ TAVARES, 2003, p. 27.
} 
também algumas questões sobre a real legitimidade da sua titularidade, dentro de uma perspectiva essencialmente democrática.

Em termos metodológicos, considerando-se a própria natureza do trabalho, utilizou-se como base fundamental a pesquisa bibliográfica, analisando-se as obras dos mais destacados autores que se dedicam ao tema ora em exame e por meio do estudo da legislação nacional e internacional que versa sobre a matéria. Buscando-se obter um panorama abrangente sobre o tema, procedeu-se a uma leitura comparativa e interpretativa, destacando o conteúdo relevante e as questões polêmicas, com o objetivo de, após criteriosa reflexão, estabelecer uma visão crítica acerca do tema, posicionando-se afinal sobre o assunto.

\section{O PODER CONSTITUINTE ORIGINÁRIO COMO PODER POLÍTICO}

A noção de poder constituinte, em uma concepção contemporânea, se relaciona fundamentalmente à idéia de Constituição escrita, no sentido de ser ele "a energia ${ }^{3}$ inicial que institui uma determinada ordem jurídica, criando ou reconstruindo um Estado através de uma Constituição, que é a primeira expressão do direito positivo" ${ }^{4,}$.

E, considerando ser a Constituição, obra do poder constituinte originário, o documento que, na tricotomia clássica, define e enquadra legalmente os poderes ditos constituídos legislativo, executivo e judiciário -, fazendo com que não possam ser exercidos senão no âmbito previamente estabelecido por ela, além de estruturar a forma e sistema de governo, os mecanismos eleitorais, dentre outras matérias, implica dizer que, mesmo que de forma mediata, há um indissociável viés político nos fundamentos do poder constituinte.

Por outro lado, importa mencionar que, ao lado da tradicional divisão do poder constituinte em originário e derivado, surge também, com base na dupla perspectiva, material e formal, sobre a Constituição de um Estado, a conceituação de um poder constituinte material e outro formal.

Distinguem-se ambos pelo fato do material ser o "poder de autoconformação do Estado segundo certa idéia de Direito", enquanto o formal pode ser entendido como "um

\footnotetext{
${ }^{3}$ O termo "energia", relata André Ramos Tavares, também é utilizado por George Burdeau para se referir ao poder constituinte originário, pelo fato de "poder" pressupor um quadro de competências, o delineamento da extensão de seu exercício e sua ligação com uma regra anterior, que lhe validará a existência, enquanto a "força" ou "energia constituinte" se manifesta como ruptura plena, revolucionária ou que se relacione à independência de um Estado. TAVARES, 2003, p. 29.

${ }^{4}$ BARROSO, 2001, p. 72.

${ }^{5}$ MIRANDA, 2003, p. 357.
} 
poder de decretação das normas com a forma e a força jurídica próprias das normas constitucionais ${ }^{6 \%}$.

Ainda que ambos integrem uma mesma realidade, é intuitivo observar que o aspecto material precede o formal, pela simples razão de que, pela lógica, a idéia do Direito antecede a elaboração de suas regras. Ademais, historicamente, a formalização das normas que regerão certo Estado é sempre posterior à consagração de certo regime no poder.

Acima de tudo, porém, verifica-se que tal divisão expõe de forma muito clara a vertente primordialmente política do poder constituinte, não sendo possível dissociar o estudo do tema desta premissa, como bem apontado por Carl Schmitt ${ }^{7}$ :

\begin{abstract}
Poder constituyente es la voluntad política cuya fuerza o autoridad es capaz de adoptar la concreta decisión de conjunto sobre modo y forma de la propia existencia política, determinando así la existencia de la unidad política como un todo. De las decisiones de esta voluntad se deriva la validez de toda ulterior regulación legalconstitucional. Las decisiones, como mías, son cualitativamente distintas de las formaciones legal-constitucionales establecidas sobre su base.
\end{abstract}

A corroborar tal entendimento, Carlos Ayres Britto ${ }^{8}$ argumenta que toda a força que tem o poder constituinte "para fazer o que bem entender do Direito", só se justifica por ser ele uma realidade exclusivamente política, e não jurídica. Do contrário, segue argumentando, se jurídico fosse este poder, ele já faria parte do Direito e ao Direito teria que se submeter.

No mesmo sentido é a posição de Meirelles Teixeira, que afirma ser o poder constituinte a expressão mais alta do poder político. E define ainda este poder político como "a possibilidade concreta, que assiste a uma comunidade, de determinar o seu próprio modo de ser, os fins e os limites de sua atuação, impondo-os, se necessário, a seus próprios membros, para consecução do Bem Comum" ${ }^{9}$.

De fato, o próprio surgimento da Teoria do Poder Constituinte teve inegável motivação política. As idéias do abade Sieyès, na época, se pautavam na situação de desprestígio do chamado Terceiro Estado (composto basicamente pela burguesia) frente à nobreza e ao clero, sobretudo quanto à pouca representatividade de seu voto nas reuniões dos Estados Gerais, fazendo com que este grupo, apesar de numericamente mais expressivo que os outros dois juntos, tivesse de, quase sempre, se submeter à vontade decisória dos demais ${ }^{10}$.

\footnotetext{
${ }^{6}$ Ibidem.

${ }^{7}$ SCHMITT, 1996, p. 93-4.

${ }^{8}$ BRITTO, 2006, p. 33.

${ }^{9}$ TEIXEIRA, 1991, p. 201-2.

${ }^{10}$ Importa assinalar, neste ponto, a advertência de Paulo Bonavides, no sentido de deixar claro o fato de que "poder constituinte sempre houve, porque jamais deixou de haver o ato de uma sociedade estabelecendo os fundamentos de sua própria organização. O que nem sempre houve, porém, foi uma teoria deste poder, cuja
} 
Observa-se assim que, em última análise, ao sustentar que a composição dos Estados Gerais não permitia a representação da nação (identificada com o Terceiro Estado), buscavase manifestar as reivindicações da burguesia contra o absolutismo, com a finalidade de legitimar e limitar o poder arbitrário do Estado, em um pleito de caráter essencialmente político.

A solução, então, estaria na promulgação de uma nova Constituição, a ser elaborada com a efetiva participação dos representantes da nação, de modo a expressar, afinal, os interesses do Terceiro Estado, que era definido por Sieyès como "o conjunto dos cidadãos que pertencem à ordem comum ${ }^{11}$ ".

Neste aspecto, como noção política, o poder constituinte tem por objetivo principal o de fazer com que a nação ou o povo, dependendo da concepção que se adote, sejam os verdadeiros sujeitos da soberania, de modo que seja sempre a vontade dos governados a que prevaleça e obrigue os poderes constituídos, por meio dos preceitos inscritos na Constituição.

Justifica-se aí a afirmativa de Paulo Bonavides ${ }^{12}$, no sentido de ser a teoria do poder constituinte basicamente uma teoria da legitimidade do poder, cujo surgimento teve como inspiração as doutrinas da soberania nacional e da soberania popular.

Discorrer sobre a legitimidade deste poder, entretanto, implica em, preliminarmente, assentar em bases firmes a definição daquele que poderá ostentar a qualidade de titular do poder constituinte originário, dado que tal informação irá influenciar sobremaneira o tratamento do tema.

\section{A TITULARIDADE DO PODER CONSTITUINTE ORIGINÁRIO}

A questão da titularidade do poder constituinte reside em "saber a que entidade política compete a faculdade de dar à nação a Constituição ${ }^{13}$ ". Significa dizer que, na verdade, o titular deste poder será, ao menos sob o aspecto formal, o correspondente ao titular da soberania, dado que, como já exposto, o poder constituinte consiste na mais alta expressão do poder político, pelo fato de se dedicar à elaboração da estrutura fundamental do Estado e da sociedade.

aparição configura um traço de todo original, ou seja, uma peculiaridade digna talvez de justificar o pasmo e a vaidade do orador constituinte, ao formulá-la em fins do século XVIII". BONAVIDES, 1998, p. 121.

${ }^{11}$ SIEYÈS, 2001, p. 8.

${ }^{12}$ BONAVIDES, 1998, p. 120.

${ }^{13}$ SALDANHA, 1986, p. 73. 
Com efeito, Paulo Bonavides afirma que o poder constituinte, em seu sentido político, "só tem uma função capital: a de fazer que a Nação ou o Povo, os governados enfim, sejam os sujeitos da soberania ${ }^{14,}$.

Neste ponto, portanto, necessário fazer uma breve digressão sobre as três principais teorias, dentre todas aquelas identificadas pela Ciência Jurídica, a respeito da titularidade da soberania.

De início, predominavam as teorias da soberania divina, segundo as quais o poder político emana de Deus, seja pela investidura direta do agente por intervenção divina ou pela sua escolha, baseada em acontecimentos que também tivessem a marca do divino, ainda que indiretamente. Tais teorias foram bastante utilizadas para justificar o absolutismo e não se coadunam com o sentido do constitucionalismo, que exige a eliminação de qualquer conteúdo pessoal na elaboração das normas.

Com o decorrer dos tempos, surgem as teorias da soberania popular, sendo JeanJacques Rousseau um de seus maiores expoentes. Nestas, a soberania é atribuída aos cidadãos, "considerados como complexo de pessoas que participam da vida política do Estado $^{15,}$, na expressão de uma vontade geral, que equivaleria ao interesse comum.

Quanto às teorias da soberania nacional, que tiveram seu ponto de consolidação na Revolução Francesa, sustentam que a soberania é atribuída à nação, sendo esta entendida como uma entidade abstrata, que transcende o conceito de povo, eis que este tem interesses momentâneos, enquanto que os daquela são permanentes.

Na concepção de Sieyès, o titular do poder constituinte seria a nação, exatamente pelo fato de entender, na distinção entre povo e nação, que só esta última expressaria os interesses permanentes de uma comunidade, inclusive (e principalmente) sob a ótica política. Já o povo seria uma simples associação de homens, unidos por alguma coincidência étnica ou cultural, mas não necessariamente política. Ou seja, o importante para este autor era deixar clara a idéia de supremo poder da coletividade, que tem interesses comuns e permanentes.

Hoje, contudo, assevera Manoel Gonçalves Ferreira Filho, “a opinião esmagadoramente predominante é a de que o supremo poder, num Estado, pertence ao povo; a soberania é do povo; portanto, o Poder Constituinte é do povo ${ }^{16,}$.

\footnotetext{
${ }^{14}$ BONAVIDES, op. cit., p. 128.

${ }^{15}$ MORAES, 2004, p. 15.

${ }^{16}$ FERREIRA FILHO, 1999, p. 30.
} 
Assim, considerando-se o povo como titular do poder constituinte, resta formalmente atendida a moderna exigência de participação popular na deliberação das questões fundamentais do Estado.

Entretanto, é inegável que, em termos práticos, pela própria complexidade da civilização e do significativo incremento do número de indivíduos em todas as partes do globo, o povo, como tal, não poderia se governar diretamente e tampouco conseguiria dar a si mesmo uma Constituição.

Por outro lado, o governo, isoladamente, também não teria fundamento (dentro de uma concepção moderna em que não mais se admitem as práticas arbitrárias do absolutismo), para, sem a anuência popular, decidir sobre toda a organização estatal, razão pela qual Nelson Saldanha afirma que "a complementariedade, modernamente admitida, entre povo e governo, faz que se deva repartir entre os dois o título de portador do poder constituinte ${ }^{17,}$.

Surge aí a noção de representação, baseada em uma relação de confiança entre governantes e governados, com a existência de interesses comuns a todos, e que vai possibilitar ao povo assumir, por intermédio do governo, a titularidade do poder constituinte $^{18}$. De fato, afirma Tércio Sampaio Ferraz Júnior que "a idéia de que o poder originário esteja no povo é inseparável da idéia de representação ${ }^{19}$ ".

Nesta ordem de idéias, Jorge Miranda assim analisa o fenômeno da representação política, visando deixar claro o seu conceito:

Cuida-se, sim, de representação do povo enquanto modo de tornar o povo (ou o conjunto dos governados) presente no exercício do poder através de quem ele escolha ou de quem tenha a sua confiança. A representação política é o modo de o povo, titular do poder, agir ou reagir relativamente aos governantes ${ }^{20}$.

$\mathrm{Na}$ verdade, esta concepção corresponde aos ideais hodiernos, vigentes no Ocidente, de que as Constituições devem, preferencialmente, ser a expressão de uma identidade relativa entre governantes e governados, como corolário dos princípios democráticos.

A democracia, assim, "significando a idéia de um governo em que coincidam os sujeitos ativo e passivo das decisões ${ }^{21 ",}$, conseguiria oferecer a tão almejada aproximação

\footnotetext{
${ }^{17}$ SALDANHA, 1986, p. 74.

18 Importa registrar que, a visão de Rousseau, principal teórico da teoria da soberania popular, é radicalmente contrária às idéias de representação, sob o argumento de que "não se pode representar a soberania pela mesma razão que se não pode alienar; consiste ela essencialmente na vontade geral, e a vontade não se representa; ou ela é a mesma, ou outra, e nisso não há meio termo", na defesa da adoção da democracia direta que, atualmente, em termos práticos, não tem como se sustentar. ROUSSEAU, 2003, p. 91.

${ }^{19}$ FERRAZ JÚNIOR, 1985, p. 24.

${ }^{20}$ MIRANDA, 2007, p. 49.

${ }^{21}$ MIRANDA, 2007, p. 49.
} 
entre o povo e aqueles indivíduos que têm a missão de orientar, coordenar e de fato decidir o destino de todo o grupo, ao exercer, em nome destes, o poder constituinte.

Há que se observar, contudo, que, ao encampar tal premissa, exsurgem duas grandes questões, que se revelam de capital importância no debate quanto à titularidade do poder constituinte: a definição de povo e a confirmação da legitimidade da representação popular.

\subsection{Considerações sobre o conceito de Povo}

Em relação ao povo, há consenso quanto à necessidade do elemento pessoal para a formação e existência do Estado, já que, sem dúvida, não há que se falar neste sem a presença dos indivíduos.

Contudo, como bem alerta Dalmo de Abreu Dallari, "o termo povo está entre aqueles que, pelo uso indiscriminado e excessivo, acabaram por tornar-se equívocos, sendo necessário um grande esforço para, antes de tudo, depurá-lo das informações e, depois disso, estabelecer sua noção jurídica ${ }^{22 \%}$.

De fato, na prática, muitas vezes o seu conceito é tomado como sinônimo de população ou mesmo de nação. A população abrange o "conjunto de pessoas que vivam no território de um Estado ou mesmo que se achem nele temporariamente 23 , , sem que daí resulte qualquer vínculo jurídico entre a pessoa e o Estado, razão pela qual não pode ser usada na mesma acepção que o termo povo.

Já a nação, termo que adquiriu grande prestígio na França do século XVIII, tampouco se apóia na existência de vínculos jurídicos, não se confundindo, portanto, com o Estado. Indica, segundo Miguel Reale, "uma comunhão formada por laços históricos e culturais e assentada sobre um sistema de relações de ordem objetiva ${ }^{24,}$, implicando na identificação de uma comunidade em que todos partilham certo ambiente cultural, mantido por arraigadas tradições e costumes e visando ideais comuns à coletividade.

A dificuldade em obter-se uma definição unívoca do que se entende como povo motivou Friedrich Müller a empreender um valioso esforço doutrinário, de modo a perscrutar o tema em profundidade, não se limitando aos aspectos atinentes ao direito positivo, mas, sobretudo, priorizando-se a questão da legitimidade como foco de análise ${ }^{25}$.

\footnotetext{
${ }^{22}$ DALLARI, 1998, p. 95.

${ }^{23}$ CAETANO apud DALLARI, op. cit., p. 95.

${ }^{24}$ REALE, Miguel apud DALLARI, 1998, p. 96.

${ }^{25}$ Em obra dedicada exclusivamente ao tema, Friedrich Muller identifica alguns grupos que corresponderiam aos modos de utilização do termo "povo", a saber: (i) "Povo" como ícone, não se referindo a nenhum cidadão ou
} 
De fato, após observar que a simples indagação sobre quem é, em última instância, o povo, nunca é formulada como uma pergunta analítica, eis que se supõe tacitamente que, afinal, todos saibam quem é esse povo, o autor afirma que, de maneira geral, o emprego da expressão "povo" nos textos das normas de uma constituição visa legitimar democraticamente o poder ${ }^{26}$. Pouco se discute, entretanto, o fato de que, na verdade, a utilização "em bloco" do conceito de povo encobre sua heterogeneidade e, por conseguinte, a latente tensão entre suas reais necessidades e o agir de seus representantes eleitos. Há, portanto, nesta perspectiva, uma estreita ligação entre o desenvolvimento do conceito de povo e a existência de um Estado de Direito, em especial no que se refere aos mecanismos de efetiva participação dos indivíduos na tomada de decisões que afetem o seu cotidiano, na consagração de uma verdadeira soberania popular.

A necessidade, contudo, de estabelecer uma noção jurídica de povo, disciplinando de forma mais concreta esta entidade tão importante para o estudo do Estado, ainda que já pudessem ser encontradas inúmeras discussões sobre o assunto desde a Grécia antiga, passando pela Idade Média e alcançando o período do Estado Moderno, fez surgir a concepção de povo de uso razoavelmente corrente nos dias de hoje.

Assim, modernamente, é possível compreender como povo um conjunto de indivíduos que, em um determinado momento, "se unem para constituir o Estado, estabelecendo com este um vínculo jurídico de caráter permanente, participando da formação da vontade do Estado e do exercício do poder soberano ${ }^{27 \%}$.

E, nesta ordem de idéias, Manoel Gonçalves Ferreira Filho ${ }^{28}$ relata que, nas chamadas democracias modernas, o povo abrange os cidadãos, ou seja, aqueles aos quais a Constituição atribui direitos políticos. Isto porque não haveria outra maneira de caracterizar juridicamente o cidadão, já que o próprio Estado, por meio, em regra, de seus documentos constitucionais, estabelece determinadas condições objetivas, cujo atendimento é pressuposto para o indivíduo adquirir o direito de participar da formação da vontade coletiva e do exercício da soberania.

grupo de pessoas, mas sim a uma imagem abstrata e discursivamente construída; (ii) "Povo" como instância de atribuição de legitimidade, no sentido de que são os seus representantes eleitos que, em seu nome, elaboram as normas que, em última análise, irão vincular os interesses do próprio povo; (iii) "Povo" ativo, como aquele titular de nacionalidade, de acordo com os dispositivos do texto constitucional; e (iv) "Povo" como destinatário das prestações civilizatórias do Estado, ou seja, como titular de pretensões ao respeito dos seus direitos fundamentais e humanos. $\mathrm{O}$ autor demonstra, assim, a extrema complexidade de um conceito aparentemente simples. MÜLLER, 2010..

${ }^{26}$ MÜLLER, 2010, op. cit., p. 93

${ }^{27}$ DALLARI, op. cit., p. 99-100.

${ }^{28}$ FERREIRA FILHO, 1999, p. 31 
Ocorre que, considerando que esta aquisição de cidadania depende do preenchimento das condições fixadas pelo Estado, que não se restringem ao simples fato de ter alguém nascido em determinadas circunstâncias, mas também incluem o atendimento de certos requisitos, não requer grande esforço interpretativo, sendo mesmo intuitivo concluir que nem todos irão alcançar a qualidade de cidadãos.

A consequiência natural desta situação é que, na prática, uma parte dos indivíduos estará alijada do processo de formação desta vontade coletiva e do exercício da soberania. $\mathrm{Ou}$ seja, o conceito de povo é, de certa forma, excludente ${ }^{29}$, o que acaba por conduzir a uma outra questão, como já apontado, que se refere à legitimidade dos representantes escolhidos para exercer, em nome do grupo, a soberania estatal.

\subsection{A questão da legitimidade da representação popular}

A democracia do tipo representativo, usualmente adotada na maior parte dos países que, hoje, se intitulam como democráticos, pressupõe a existência de um conjunto de instituições que disciplinam a participação popular nas decisões estatais, vindo a formar os direitos políticos que são a base da cidadania, dentre os quais se incluem, entre outros, as eleições, os sistemas eleitorais e os partidos políticos.

Significa dizer, assim, que a eleição é uma técnica da democracia representativa, pela qual os cidadãos expressam uma preferência entre as alternativas oferecidas, aderindo, por consequiência, a certo viés político e conferindo legitimidade às autoridades governamentais. E é desta forma que o povo participa da formação da vontade estatal e do processo político.

Trata-se, segundo José Afonso da Silva, do "princípio da representação", que se fundamenta na eleição e se efetiva pelo mandato político representativo. Este constitui, em essência, "situação jurídico-política com base na qual alguém, designado por via eleitoral, desempenha uma função político-governamental na democracia representativa ${ }^{30}$ ".

Há que se observar, porém, que, se em teoria, a construção e desenvolvimento deste processo funciona de modo bastante satisfatório, na prática nem sempre é possível afirmar o mesmo. Como já apontado, aos cidadãos raramente corresponde a totalidade do povo, o que justificam os questionamentos sobre a legitimidade desta representação.

\footnotetext{
${ }^{29}$ De fato, Manoel Gonçalves Ferreira Filho, ao comentar o tema, relata, a título de exemplo, que, no Brasil, a participação política não é atribuída a todos, tendo em vista que dela estão excluídos os analfabetos, o que, segundo o autor, importa praticamente na exclusão de metade da população brasileira em condições, pela idade, da participação desse processo político. FERREIRA FILHO, 1999, p. 31.

${ }^{30}$ SILVA, 2007, p. 48.
} 
Com efeito, diante de tal panorama, é possível afirmar, com esteio em Manoel Gonçalves Ferreira Filho, que o povo é um titular passivo do poder constituinte, ao qual se imputa uma vontade constituinte sempre manifestada por uma elite. Ou seja, "a edição de uma Constituição provém sempre de um grupo que em lugar do povo propõe uma organização do poder político. Tal grupo se põe como agente do Poder Constituinte e é assim o titular ativo deste poder naquela manifestação ${ }^{31}$ ".

Esta é a razão pela qual, de modo bastante enfático, Friedrich Müller critica a concepção usualmente aceita de que é o povo que constitui para si a Constituição, fazendo uso da estrutura da representação política:

\begin{abstract}
Se o poder compete "ao povo", isso exige um procedere democrático. Mas aqui entra a alegoria da representação, um amplo leque de tipos procedimentais possíveis, que então acabam sendo atribuídos "ao povo" - não importa quão elitistamente, quão mediatamente. Com efeito, nunca é "o" povo que constitui (para si) a Constituição, também não no caso da aclamação, nem no caso da votação secreta com resultado majoritário, nem no caso da anuência por via de representantes ${ }^{32}$.
\end{abstract}

Não é outro o entendimento de José Afonso da Silva ${ }^{33}$ sobre o tema, ao afirmar que o mandato representativo tem algo de ficção. Isto porque não se poderia nem mesmo considerar como representação uma simples técnica de formação dos órgãos governamentais, a que se reduziria o princípio da participação popular e o princípio do governo pelo povo.

Deste modo, a idéia de representação toma como premissa a identidade entre representantes e representados, da qual decorreria a crença de que ao decidirem aqueles, é como se decidissem os representados, na consagração de um verdadeiro autogoverno do povo. $\mathrm{Na}$ prática, porém, constata-se que esta concepção não subsiste, resultando daí grandes prejuízos quanto à legitimidade deste processo.

Vale registrar, contudo, a posição de Manoel Gonçalves Ferreira Filho ${ }^{34}$, segundo o qual, mesmo se admitindo os problemas quanto à constituição do povo e as possíveis falhas quanto à legitimidade de sua representação, isto não afasta o importante papel do povo no processo constituinte.

Isto porque só o povo poderá conferir eficácia, cumprimento global, ao documento constitucional editado. E, sem tal eficácia, a Constituição não é direito, tomando como base a conhecida lição de Kelsen, para quem a eficácia é condição de validade da ordem jurídica.

\footnotetext{
${ }^{31}$ FERREIRA FILHO, 1999, p. 31.

${ }^{32}$ MÜLLER, 2004, p. 112-113.

${ }^{33}$ SILVA, 2007, p. 49.

${ }^{34}$ FERREIRA FILHO, op. cit., p. 32.
} 
Entretanto, isto não exclui o fato de que a titularidade do poder constituinte originário resta comprometida nesta linha de raciocínio. Se é certo que a ordem democrática não se restringe à questão das eleições, mas inclui também a participação popular por outros meios, tais como as manifestações públicas, tampouco se pode ignorar que, tratando-se do poder de elaborar uma nova ordem constitucional, é pelo voto que serão escolhidos aqueles que, em nome do povo, irão elaborar o documento que, em sentido amplo, irá reger toda a estrutura do Estado.

Ademais, no tocante às manifestações públicas, estas tampouco têm o condão de agregar o povo em sua integralidade, acabando por reiterar o seu conceito seletivo, já que normalmente mobilizam um grupo parcial de pessoas politicamente informadas e interessadas em um conteúdo específico de protesto.

Nesta ordem de idéias, observa Friedrich Müller ${ }^{35}$, de modo bastante cético, que as pessoas, de maneira geral, são inertes em matéria de política constitucional e, portanto, pouco treinadas a perceber e defender as suas possibilidades de autodeterminação neste aspecto, estando ocupadas com aqueles assuntos corriqueiros que lhe são mais próximos, na tentativa de (sobre)viver materialmente.

Considerando-se, então, que se revela bastante possível a caracterização de uma situação em que os representantes do povo não possam ser, de fato, identificados com o conjunto de indivíduos que constituem o Estado, justificar-se-ia o estabelecimento de alguma espécie de limite ao exercício do poder constituinte originário, de modo a garantir a efetiva elaboração de um documento constitucional que reflita os anseios do povo - titular daquele poder - e resguarde seus direitos.

\section{LIMITAÇÕES AO PODER CONSTITUINTE ORIGINÁRIO}

O poder de fundar uma nova ordem jurídica, por meio da criação de uma Constituição é, na plena acepção do termo, livre e incondicionado e, sob o aspecto positivo, um poder préjurídico, antecedendo o próprio Direito. Mas, por outro lado, também é um poder que visa um determinado fim, orientado por um objetivo jurídico e, deste modo, passível de controle e essencialmente limitado.

Nelson Saldanha ${ }^{36}$ argumenta que se o poder constituinte não fosse limitado, não seria jurídico. E se, por outro lado, o fosse completamente limitado não seria um poder

\footnotetext{
${ }^{35}$ MÜLLER, 2004, p. 96-7.

${ }^{36}$ SALDANHA, 1986, p. 90.
} 
sociologicamente distinto e nem constituinte. Na proporção de seus limites, então, é que estariam os seus alcances, pois na medida em que é restringido é que lhe são fornecidas as mais concretas perspectivas de atuação.

Entretanto, verifica-se que, na prática, a concepção usualmente encontrada na maior parte dos Manuais ${ }^{37}$ é aquela que imputa ao poder constituinte originário uma tríplice caracterização, repetida como um verdadeiro dogma, no sentido de ser este inicial, incondicionado e ilimitado.

Com efeito, há que se admitir seu caráter inicial, eis que tem o poder constituinte originário a função de elaborar uma Constituição, documento que é a base da ordem jurídica do Estado. Tampouco se questiona o fato de ser considerado como incondicionado, tendo em vista a não sujeição a qualquer forma prefixada para manifestar sua vontade, não havendo um procedimento específico para tal. A caracterização deste poder como ilimitado, porém, não se revela de todo pacífica, sendo encontrados posicionamentos que se insurgem contra tal opinião.

O constitucionalista português Jorge Miranda ${ }^{38}$, por exemplo, é um dos que admite expressamente a existência de limites ao poder constituinte. E, de modo a bem marcar sua posição, assinala que, embora seja mais corrente na doutrina considerar a existência de limites materiais do poder de revisão constitucional (ou poder constituinte derivado), não se pode deixar de considerar a existência de limites materiais (ainda que em graus diversos) do poder constituinte originário, por ele denominado de verdadeiro e próprio.

Nesta ordem de idéias, distingue este autor três categorias de limites materiais ao poder constituinte: limites transcendentes, imanentes e heterônomos.

Os limites transcendentes são aqueles que se impõem à vontade do Estado (ou, em termos democráticos, à vontade do povo) e provêm do Direito natural, como valores éticos superiores, emanados de uma consciência coletiva. Dentre eles se incluiriam os direitos fundamentais relacionados com a dignidade da pessoa humana, tendo em vista que seria inválido ou ilegítimo decretar normas constitucionais que, de alguma forma, os ofendessem.

Além destes, existiriam também os limites imanentes, os quais decorrem da noção e do sentido do poder constituinte formal enquanto poder estabelecido, identificado por certa origem e finalidade e que se manifesta sob certas circunstâncias. Estariam aí compreendidos os limites referentes à soberania do Estado, bem como à sua forma e à legitimidade política em concreto.

\footnotetext{
${ }^{37}$ Por todos, MORAES, 2004, p. 58.

${ }^{38}$ MIRANDA, 1996, p. 106.
} 
Complementam este rol os limites heterônomos, provenientes da relação com outros ordenamentos jurídicos, tanto podendo referir-se às regras ou atos de Direito Internacional como às de Direito interno, em caso de Estado composto ou complexo, e assim tenha de ser seu ordenamento. Os primeiros referem-se às limitações de conteúdo da Constituição em função dos deveres assumidos pelo Estado com outros Estados ou para com a comunidade internacional. Já os segundos são os chamados limites recíprocos, típicos de federações, entre o poder constituinte federal e o dos estados federados, cuja coexistência depende do respeito a certas balizas.

No mesmo sentido, Bidart Campos ${ }^{39}$, embora admitindo que o poder constituinte, ao fundar um Estado, não se ache condicionado por instâncias positivas, podendo conferir qualquer conteúdo à Constituição que venha a elaborar, alerta que isto não significa ser este totalmente ilimitado.

Isto porque, acima das instâncias positivas, há que se reconhecer a existência do direito natural ou da justiça, que impõem critérios de valor que a vontade humana não pode simplesmente ignorar. Assim, é possível enumerar certas questões a que todos os documentos constitucionais deveriam, necessariamente, ajustar-se, dentre os quais se incluem a dignidade da pessoa humana, os direitos individuais, a chamada "justiça social" e a liberdade.

Além destes, considerados como valores transcendentes, afirma o autor que todo poder constituinte deveria ainda seguir certas diretrizes, as quais, inevitavelmente, também funcionam como limitações, relacionadas ao próprio ambiente social e histórico daquela comunidade em particular.

Com efeito, não se pode aceitar que as Constituições sejam meros esquemas teóricos, elaborados abstratamente. Tanto o passado quanto o presente da sociedade fornecem elementos que não podem ser desconsiderados, sob pena de estabelecer-se uma estrutura dissociada por completo da realidade e que, por conseqüência, tenha sua vigência prejudicada. As tradições, os costumes e as práticas sociais devem orientar os trabalhos constituintes, "porque las constituciones se hacen para los pueblos, y no los pueblos para las constituciones ${ }^{40}$,

Outro não é o entendimento de Nelson Saldanha ${ }^{41}$, o qual, após assinalar genericamente, mas de forma bastante firme, ser o poder constituinte limitado, eis que

\footnotetext{
${ }^{39}$ CAMPOS, 1972, p. 524.

${ }^{40}$ CAMPOS, 1972, p. 525.

${ }^{41}$ SALDANHA, 1986, p. 91-2.
} 
orientado por um objetivo jurídico, como já apontado, passa a discorrer mais detalhadamente sobre o tema, de modo a melhor aclarar seu posicionamento.

Enfatiza, nesta ordem de idéias, a existência de duas espécies de limites, relacionados, no plano interno, com a soberania (que, paradoxalmente, também é fonte do poder constituinte) e com os princípios gerais de direito, e, por outro lado, com o fenômeno da crescente intensificação da vida internacional.

A soberania consiste, para o autor, em um limite básico de todo poder constituinte, pois seu atuar se restringe, por óbvio, aos limites físicos ou espaciais por ela abarcados. Limites fundamentais a este poder seriam, também, aqueles decorrentes dos princípios gerais do direito, sob o ponto de vista da justiça e dos valores essenciais a esta relacionados, com destaque para aqueles concernentes às liberdades individuais, necessariamente consagrados por todas as Constituições dos Estados que se intitulem como democráticos.

Quanto à questão da internacionalização, trata-se de um processo que tem se intensificado na atualidade, diante do incremento das relações entre os Estados, com a conseqüente assunção de compromissos interestatais, que trazem reflexos inevitáveis nos documentos constitucionais e geram uma série de desdobramentos e dificuldades jurídicas.

Observa-se, portanto, que a possibilidade de instituírem-se limites ao poder constituinte originário não é de todo estranha à doutrina, ainda que não exista, na verdade, consenso a que se refeririam os mesmos, podendo ser relacionadas as mais diversas opiniões neste sentido.

\section{OS TRATADOS DE DIREITOS HUMANOS COMO LIMITAÇÃO MATERIAL AO PODER CONSTITUINTE ORIGINÁRIO}

Apresentada a questão concernente à duvidosa legitimidade em torno da real titularidade do poder constituinte enquanto poder político, diante da constatação de falhas no processo de representação popular, aliada à admissibilidade doutrinária da aposição de limites ao poder constituinte originário, propõe-se que sejam os tratados internacionais de direitos humanos identificados como a legítima limitação material a este poder, visando o fortalecimento dos ideais democráticos no âmbito estatal.

O poder constituinte e a democracia são destacados por Antonio Negri como conceitos correspondentes e que sempre estiveram inseridos em um processo histórico que, com o passar dos tempos, fez com que se identificassem cada vez mais: 
[...] o poder constituinte não tem sido considerado apenas a fonte onipotente e expansiva que produz as normas constitucionais de todos os ordenamentos jurídicos, mas também o sujeito desta produção, uma atividade igualmente onipotente e expansiva. Sob este ponto de vista, o poder constituinte tende a se identificar com o próprio conceito de política, no sentido com que este é compreendido numa sociedade democrática. Portanto, qualificar constitucional e juridicamente o poder constituinte não será simplesmente produzir normas constitucionais e estruturar poderes constituídos, mas sobretudo ordenar o poder constituinte enquanto sujeito, regular a política democrática ${ }^{42}$.

Assim, de modo a assentar em bases firmes os princípios democráticos que devem nortear a estrutura política dos Estados e preservar sua legitimidade, não pode o poder constituinte, ao elaborar o documento que institucionalizará "o domínio de homens sobre homens $^{43}$, , afastar-se dos direitos da pessoa humana.

Significa dizer que, nos Estados de matriz democrática ou que, ao menos, tenham a consolidação da democracia por objetivo, a estrutura de domínio só resta plenamente justificada quando o poder se institua pela vontade do povo e tenha por finalidade a emancipação humana, por meio, sobretudo, da garantia de acesso àqueles direitos universalmente reconhecidos aos indivíduos.

Trata-se, assim, do reconhecimento de que a promoção dos chamados direitos humanos é um fator indissociável da própria concepção de democracia, razão pela qual, sem sombra de dúvidas, ao priorizar aqueles, tem-se o fortalecimento desta última.

A questão, porém, é identificar que direitos humanos deverão ser reconhecidos e potencializados, inserindo-se naquele catálogo dos constitucionalizados como fundamentais, a fim de possa ser reconhecido como legítimo o poder político estatal.

Não há, de fato, uma solução simples para tal problema, considerando-se que os valores que lastreiam tais direitos não têm um significado único em todos os locais do globo, permitindo, muitas vezes, que os interesses jurídicos, políticos e outros correlatos dominem as discussões, em detrimento do único enfoque que deveria subsistir, qual seja, o na pessoa humana.

Por outro lado, importa registrar, com arrimo em Luzia Cabral Pinto ${ }^{44}$, que, ao se propor o uso dos direitos humanos como limitação ao poder constituinte e, por conseqüência, critério legitimador do exercício do poder político, não significa que "comunguemos da 'ilusão iluminista' da existência de um catálogo eterno e imutável de direitos inerentes a uma

\footnotetext{
${ }^{42}$ NEGRI, 2002, p. 7.

${ }^{43}$ PINTO, 1994, p. 142.

${ }^{44}$ Idem, p. 143.
} 
natureza humana transcendente, abstracta e metafísica (direitos originários preexistentes à ordem positiva)".

Isto porque, a despeito de ser sedutora a tese de que os direitos humanos dispensam maiores considerações sobre sua fundamentação, tendo em vista suas características eternas e imutáveis, forçoso admitir que tal concepção se revela por demais vaga e abstrata, não conferindo grande auxílio ao propósito de funcionar como elemento limitador do poder constituinte originário.

Deste modo, entende-se que, na prática, o reconhecimento de tais direitos por determinado Estado decorre de uma opção política, normalmente mediante a inserção, nos seus documentos constitucionais, de um rol de direitos, que passam a ser classificados como fundamentais, ainda que o cenário ideal, inegavelmente, fosse aquele em que todo e qualquer indivíduo pudesse, sem ter de depender de uma decisão alheia, gozar de todos os benefícios disponíveis.

Além do processo de constitucionalização de direitos, que dificilmente esgota o tema por completo, a materialização desta opção política se dá também, hodiernamente, por meio da adesão do Estado aos tratados internacionais de direitos humanos, documentos de abrangência mundial, que veiculam de forma explícita, por meio de normas positivadas de cumprimento obrigatório por aqueles que a ele adiram, o que abstratamente se convencionou denominar de direitos humanos.

No tocante aos tratados internacionais, em que pese serem identificados como juridicamente obrigatórios e vinculantes (pacta sunt servanda), só se aplicam, com bem assinala Flávia Piovesan ${ }^{45}$, aos Estados-partes, ou seja, aos Estados que expressamente consentiram com sua adoção, não podendo estes documentos criar obrigações para quem deles não consentiu, razão pela qual, ao aceitá-lo, um Estado soberano se compromete a respeitar seus preceitos.

E, considerando que são as exigências sociais de cada momento histórico, muitas vezes decorrentes de árduos processos de luta política ou da constatação de que a prática de certas condutas contrárias à dignidade da pessoa humana não mais devem ser aceitas, que conduzem à institucionalização dos direitos humanos, verifica-se que os tratados acabam por funcionar como marcos fundamentais de todo este processo.

\footnotetext{
${ }^{45}$ PIOVESAN, 2006, p. 45.
} 
Significa dizer, então, nesta ordem de idéias, que "os valores que se vão inscrevendo no conteúdo dos direitos humanos têm um fundamento histórico-empírico, não metafísico ${ }^{46,}$, em uma concepção que também encontra respaldo no entendimento de Pérez Luño:

\begin{abstract}
Ello implica cifrar la fundamentación de los derechos humanos en el despliegue multilateral y consciente de las necesidades humanas, que emergen de la experiencia concreta de la vida práctica. Esas necesidades, em cuanto datos social e históricamente vinculados a la experiencia humana, poseen una objetividad y una universalidad que posibilitan su generalización, a través de la discusión racional y el consenso, y su concreción en postulados axiológico-materiales. El sistema de valores o preferencias conscientes básicos debe servir, en suma, 'para maximizar y optimizar la satisfacción de las necesidades e intereses de todos y cada uno de los miembros de la especie humana, ${ }^{47}$.
\end{abstract}

É possível afirmar, deste modo, que os tratados que cuidam da temática dos direitos humanos expressam as necessidades sociais que surgem e se desenvolvem na vida dos homens ao longo do tempo, em âmbito mundial, o que explica a contínua elaboração de novos documentos, abordando não só assuntos inéditos como expressando novas visões sobre matérias mais antigas.

E, sendo assim, no momento em que um Estado decide aderir a um determinado tratado internacional que verse sobre direitos humanos, comprometendo-se a adotar, em seu âmbito de jurisdição, certos valores de promoção da pessoa humana que vêm a ser agregados aos que eventualmente já eram reconhecidos pelo mesmo, estabelece ali um marco que não admitiria supressão, sob pena de um odioso retrocesso, o que se estende também para a hipótese de elaboração de uma nova Constituição, situação em que o poder constituinte originário restaria limitado por aqueles documentos internacionais.

Não se ignora que tal concepção é passível de acirradas críticas, sobretudo pelo argumento daqueles que defendem a soberania estatal como dogma absoluto, não admitindo que as regras de direito internacional possam validamente subsistir diante de eventual conflito com as normas internas.

Sem adentrar ao mérito da polêmica vinculação dos preceitos de direito internacional no âmbito interno dos Estados, eis que tal discussão refoge aos objetivos do presente trabalho, cabe ressaltar que o que se defende aqui é a limitação do poder constituinte pelos tratados internacionais que versem especificamente sobre direitos humanos, os quais, por seu especial conteúdo, devem estar inseridos em um plano diferenciado, sem comportar o mesmo tratamento dos documentos internacionais "comuns". E, por óbvio, parte-se da premissa de que a referida limitação implique em um incremento aos direitos já existentes, eis que não se

\footnotetext{
${ }^{46}$ PINTO, 1994, p. 145.

${ }^{47}$ LUÑO, 1999, p. 182.
} 
admite, sob qualquer fundamento, defender a incorporação de alguma previsão que importe em retrocesso às normas existentes.

Esta linha de raciocínio, na verdade, mostra-se em consonância com as recentes transformações sociais e democráticas que têm sido observadas na América Latina, de que são exemplos emblemáticos as Constituições da Bolívia, de 2009 e do Equador, de 2008 que, sem abandonarem a opção pela democracia representativa, procuram somar a esta um forte componente de democracia participativa, de modo a suprir os problemas da representatividade deficiente de certos grupos, além de admitirem a abertura a outras normas protetivas aos direitos humanos, ainda que advindas do plano internacional ${ }^{48}$.

Identifica-se, aí, o surgimento dos denominados "Estados Plurinacionais", que se caracterizam, fundamentalmente, pela capacidade de criarem espaços de diálogo permanente, em que todas as partes compareçam em condições de igualdade, sem, entretanto, enquadrarem-se em uma tradicional proposta culturalista (que muitas vezes se presta a encobrir violações de direitos e autoritarismo) ou universalista (com o risco de imposição de valores para justificar a dominação e o interesse de outras potências). Como já se bem observou:

A grande revolução do Estado Plurinacional é o fato que este Estado constitucional, democrático participativo e dialógico pode finalmente romper com as bases teóricas e sociais do Estado nacional constitucional e democrático representativo (pouco democrático e nada representativo dos grupos não uniformizados), uniformizador de valores e logo radicalmente excludente. O Estado plurinacional reconhece a democracia participativa como base da democracia representativa e garante a existência de formas de constituição da família e da economia segundo os valores tradicionais dos diversos grupos sociais (étnicos e culturais) existentes ${ }^{49}$.

\footnotetext{
${ }^{48}$ Historicamente, os povos originários da Bolívia e do Equador sempre sofreram com a exclusão social e só recentemente, com a eleição de governos democráticos comprometidos com esta causa, passaram a ter seus direitos reconhecidos. No que se refere ao reconhecimento dos tratados internacionais de direitos humanos, dispõe a Constituição da Bolívia, em seu Título II, que trata das garantias e direitos fundamentais, artigo 13, IV, que "Los tratados y convenios internacionales ratificados por la Asamblea Legislativa Plurinacional, que reconocen los derechos humanos y que prohíben su limitación en los Estados de Excepción prevalecen en el orden interno. Los derechos y deberes consagrados en esta Constitución se interpretarán de conformidad con los Tratados internacionales de derechos humanos ratificados por Bolivia.". No mesmo sentido é o teor do artigo 11, 3, da Constituição do Equador, segundo o qual: "Los derechos y garantías establecidos en la Constitución y en los instrumentos internacionales de derechos humanos serán de directa e inmediata aplicación por y ante cualquier servidora o servidor público, administrativo o judicial, de oficio o a petición de parte. Para el ejercicio de los derechos y las garantías constitucionales no se exigirán condiciones o requisitos que no estén establecidos en la Constitución o la ley. Los derechos serán plenamente justiciables. No podrá alegarse falta de norma jurídica para justificar su violación o desconocimiento, para desechar la acción por esos hechos ni para negar su reconocimiento".

49 MAGALHÃES, José Luiz Quadros de; SANTOS, Reinaldo Silva Pimentel. Comunidades tradicionais, plurinacionalidade e democracia étnica e cultural. Considerações acerca da proteção territorial das comunidades de remanescentes de quilombos brasileiras a partir da ADI n ${ }^{\circ}$ 3.239. Jus Navigandi, Teresina, ano 14, n. 2381,7 jan. 2010. Disponível em: <http://jus2.uol.com.br/doutrina/texto.asp?id=14141>. Acesso em: 29 set. 2010.
} 
É possível crer que o incentivo a uma maior abertura ao diálogo, de forma ampla, tal como proposto por estes novos "Estados Plurinacionais" implicará em concepção de um Estado democrático e social de direito internacional, não mais encastelado nos estreitos limites de suas fronteiras.

De fato, tais ideias se amoldam à perspectiva de Bidart Campos, segundo o qual, se, com o reconhecimento dos direitos humanos em escala mundial o homem se tornou sujeito de direito internacional, tampouco se pode negar que, em última instância, o exercício destes direitos se dá na circunscrição do Estado ao qual pertence o indivíduo. Ou seja, "esos derechos se tienen, se gozan, se disfrutan y se ejercen por hombres que son parte de un Estado, y dentro del mundo jurídico proprio de ese Estado ${ }^{50 "}$. Impõe-se, portanto, o amplo e permanente diálogo entre os âmbitos interno e internacional.

Verifica-se existir aí um argumento adicional para tratar o conteúdo dos tratados de direitos humanos como limite material ao poder constituinte originário, tendo em vista que estes documentos não poderiam ser afastados sob a simples afirmação de que pertencem exclusivamente ao direito internacional, já que é através do direito interno dos Estados que os mesmos irão se concretizar.

E, neste processo de concretização, estabelecem direitos novos ou ampliam a interpretação e aplicação dos já existentes, de sorte que, em assim sendo, passarão a estar incorporados no rol protegido e garantido pelo Estado, razão pela qual não poderia ser admitida, no futuro, sua instantânea supressão, ainda que por meio do eventual exercício do poder constituinte originário.

Ademais, ainda que se partilhe do entendimento de que o poder constituinte originário deva ter plena liberdade para fundar uma nova ordem constitucional, ao ignorar os tratados de direitos humanos a que o Estado aderiu, sob o argumento de que a soberania estatal está acima da sociedade internacional, restam profundamente prejudicados os princípios democráticos, que deveriam sempre nortear a conduta estatal, como bem adverte Marcelo Neves:

[...] os Estados que recorrem ao princípio clássico da soberania para negar a possibilidade de controles internacionais sobre o desrespeito interno dos direitos humanos, em regra, afastam-se radicalmente do modelo de Estado de Direito. De fato, onde houver Estado Democrático de Direito, apesar das diversidades culturais, não surgirão problemas relevantes entre direitos humanos com pretensão de validade mundial e soberania do Estado. Ao contrário, tenderá a haver um crescente reconhecimento das declarações internacionais de direitos, assim como a positivação legal (inclusive constitucional) e a concretização dos respectivos conteúdos ${ }^{51}$.

\footnotetext{
${ }^{50}$ CAMPOS, 1991, p. 419.

${ }^{51}$ NEVES, 2006, p. 220-1.
} 
Observa-se, assim, a existência de uma relação de verdadeira dependência entre a democracia e os direitos humanos. A garantia de direitos aos indivíduos exige a instituição do regime democrático, pois apenas neste os requisitos da dignidade da pessoa humana podem ser plenamente atendidos, já que afastado o arbítrio do poder político. E, por outro lado, a democracia só pode ser integralmente realizada, na plena acepção do termo, por intermédio dos direitos assegurados aos indivíduos.

Depreende-se daí que a democracia se apresenta como um objetivo constante a ser perseguido e não como algo definitivamente realizado, a partir da indicação de metas que visem a realização dos direitos da pessoa humana, em um processo de consolidação da própria legitimidade, como aponta Luzia Cabral Pinto:

\footnotetext{
Uma ordem jurídico-política será tanto mais legítima quanto mais avançar neste processo de democratização - incluindo aqui quer os aspectos organizatórioparticipativos quer os aspectos materiais (estes intimamente dependentes daqueles). [...] uma ordem constitucional será tanto mais legítima quanto mais for depositando e garantindo os direitos indissociáveis da dignidade humana, sabendo nós o mútuo condicionamento entre estes e os princípios estruturantes da ordem constitucional. Só assim a constante invocação da dignidade da pessoa humana significará a libertação real de todos os homens e não funcionará como máscara legitimante de interesses particulares assimilados pelo direito ${ }^{52}$. (grifos no original)
}

Assim, a defesa da limitação do poder constituinte originário pelos tratados internacionais de direitos humanos se apresenta em perfeita consonância com a promoção dos ideais democráticos, de modo a que, valorizando-se cada vez mais os indivíduos, possa ser alcançada a almejada legitimidade do exercício deste poder.

\section{CONCLUSÃO}

A teoria do poder constituinte originário é, na maioria das vezes, discutida, ainda hoje, sob uma perspectiva doutrinária cujas bases remontam ao século XVIII, tendo por objeto a situação política específica da França naquele conturbado momento histórico.

Decorre daí a noção correntemente aceita de que este poder tem por característica primária ser ilimitado, sob o fundamento de que, ao elaborar uma Constituição para o Estado, fundando um ordenamento jurídico completamente novo, estaria investido com o manto da soberania popular, exercendo este mister como representante da vontade popular, razão pela qual restaria afastada qualquer espécie de limite à sua atuação.

${ }^{52}$ PINTO, 1994, p. 151. 
$\mathrm{Na}$ prática, entretanto, observa-se que o processo de escolha dos representantes do povo não é isento de falhas, eis que mesmo em um cenário dominado pelos preceitos da democracia representativa, nem todos os indivíduos têm, de fato, acesso aos mecanismos eleitorais que possibilitam o exercício da plena cidadania, fazendo com que as decisões passem a ser tomadas por um grupo que não necessariamente se identifica com todo o povo.

Em sendo assim, justifica-se a imposição de limites ao poder constituinte originário, de modo a compensar eventuais máculas existentes em torno da legitimidade daqueles que exercem a titularidade deste poder em nome do povo, além de garantir a preservação dos direitos dos indivíduos.

Considerando, então, que a teoria constitucional contemporânea está marcada, em âmbito mundial, entre outras questões, especialmente pela variável democrática, e que a democracia, por princípio, mantém uma relação de dependência com os direitos fundamentais dos indivíduos, propõe-se que seja o conteúdo dos tratados internacionais de direitos humanos adotado como limites materiais ao poder constituinte originário.

Justifica-se tal proposta pelo fato de que apontar como limitação a este poder simplesmente o termo "direitos humanos" se revela algo por demais vago e abstrato, o que poderia suscitar inclusive problemas no plano da interpretação, com a conseqüente falta de efetividade de todo o processo. Diante da existência, ao contrário, de um documento formal, resultado de um consenso entre Estados, é facilitado o trabalho do constituinte, que passa a ter um parâmetro objetivo como diretriz.

Assim, se críticas há a este processo, não se pode ignorar que a imposição de limites ao poder constituinte originário tem por único fim o fortalecimento dos ideais democráticos, alcançando, por consequiência, a plena valorização da pessoa humana, na desejável consagração dos ditames da justiça social em escala mundial.

\section{REFERÊNCIAS:}

BARROSO, Luis Roberto. O direito constitucional e a efetividade de suas normas: limites e possibilidades da Constituição brasileira. 5 ed. Rio de Janeiro: Renovar, 2001.

BONAVIDES, Paulo. Curso de direito constitucional. 7 ed. São Paulo: Malheiros, 1998.

BRITTO, Carlos Ayres. Teoria da Constituição. Rio de Janeiro: Forense, 2006. 
CAMPOS, Germán J. Bidart. Teoría general de los derechos humanos. Buenos Aires: Editorial Astrea, 1991.

Derecho político. $4^{\mathrm{a}}$ ed. Buenos Aires: Aguilar Argentina, 1972.

DALLARI, Dalmo de Abreu. Elementos de teoria geral do Estado. 20 ed. São Paulo: Saraiva, 1998.

FERRAZ JÚNIOR, Tércio Sampaio. Constituinte: assembléia, processo, poder. São Paulo: Revista dos Tribunais, 1985.

FERREIRA FILHO, Manoel Gonçalves. O poder constituinte. 3 ed. São Paulo: Saraiva, 1999.

HOBSBAWM, Eric. Era dos extremos: o breve século XX: 1914-1991. 2 ed. São Paulo: Companhia das Letras, 1995.

LUÑO, Antonio Enrique Pérez. Derechos humanos, Estado de derecho y Constitución. 6 ed. Madrid: Tecnos, 1999.

MIRANDA, Jorge. Formas e sistemas de governo. Rio de Janeiro: Forense, 2007.

Teoria do Estado e da Constituição. Rio de Janeiro: Forense, 2003.

Manual de direito constitucional. Tomo II. 3 ed. Portugal, Coimbra, 1996.

MORAES, Alexandre de. Direito constitucional. 15 ed. São Paulo: Atlas, 2004.

MORAES, Guilherme Peña de. Direito constitucional: teoria da Constituição. 2 ed. Rio de Janeiro: Lumen Juris, 2004.

MÜLLER, Friedrich. Quem é o povo?: a questão fundamental da democracia. Tradução Peter Naumann. $5^{\text {a }}$ Ed. São Paulo: Editora Revista dos Tribunais, 2010.

2004

Fragmento (sobre) o poder constituinte do povo. São Paulo: Revista dos Tribunais, 
NEGRI, Antonio. O poder constituinte: ensaio sobre as alternativas da modernidade. Rio de Janeiro: DP\&A, 2002.

NEVES, Marcelo. Entre Têmis e Leviatã: uma relação difícil: o estado democrático de direito a partir e além de Luhmann e Habermas. São Paulo: Martins Fontes, 2006.

PINTO, Luzia Marques da Silva Cabral. Os limites do poder constituinte e a legitimidade material da Constituição. Coimbra: Coimbra, 1994.

PIOVESAN, Flávia. Direitos humanos e o direito constitucional internacional. 7 ed. São Paulo: Saraiva, 2006.

ROUSSEAU, Jean-Jacques. Do contrato social. São Paulo: Martin Claret, 2003.

SALDANHA, Nelson. O poder constituinte. São Paulo: Revista dos Tribunais, 1986.

SCHMITT, Carl. Teoría de la Constitución. Madrid: Alianza Editorial, 1996.

SIEYÈS, Emmanuel Joseph. A constituinte burguesa. (Org. Aurélio Wander Bastos). 4 ed. Rio de Janeiro: Lumen Juris, 2001.

SILVA, José Afonso. Poder constituinte e poder popular (estudos sobre a Constituição). São Paulo: Malheiros, 2007.

TAVARES, André Ramos. Curso de direito constitucional. 2 ed. São Paulo: Saraiva, 2003.

TEIXEIRA, José Horácio Meirelles. Curso de direito constitucional. Rio de Janeiro: Forense Universitária, 1991. 